\title{
Isomer composition of tocopherols in seabuckthorn (Hippophae rhamnoides L.) seeds in forest-steppe area of Altai territory
}

\author{
Anna Zemtsova ${ }^{1, *}$, and Yury Zubarev ${ }^{1}$ \\ ${ }^{1}$ Federal Altai Scientific Center of Biothechnology, Barnaul, 659910, Russia
}

\begin{abstract}
Estimation of tocopherol isomers composition in seed oil of seabuckthorn (H. rhamnoides ssp. mongolica) varieties is represented. It has been established that $\alpha$-tocopherol is the dominant tocopherol in the lipids of the seabuckthorn seeds, the mean content of which for two years has been ranged from 2.1 (Dar Katuni) to $4.8 \mathrm{mg} / 100 \mathrm{~g}$ (Yantarnaya). In general within the evaluated group of subspecies, the mean content of $\alpha$ tocopherol was determined at $3.5 \pm 0.3 \mathrm{mg} / 100 \mathrm{~g}$. $\beta$-, $\gamma$ - and $\delta$-tocopherols were characterized by low content, accumulating an average for two years at $0.5 \pm 0.1,1.3 \pm 0.1$ and $0.7 \pm 0.3 \mathrm{mg} / 100 \mathrm{~g}$, respectively.
\end{abstract}

\section{Introduction}

Tocopherols (vitamin E) considered as one of the most important substance of lipophilic origin. They possess vitamin activity, have significant antioxidant properties that prevent lipid peroxidation by inactivating free radicals of fatty acids [1]. It has been found out that tocopherols in plants are represented by closely related by chemical structure isomers $-\alpha-$, $\beta-, \gamma-, \delta$-tocopherols [2]. They are only producing by plants and convey to human body with food, mainly as vegetable oil [3].

Seabuckthorn (Hippophae L.) is one of the most prospective horticultural crop, which synthesize oil both in pulp and seeds and widely used in industry. Tocopherols are quite valuable part of seabuckthorn oil. Several investigations on tocopherol isomers content in seabuckthorn pulp oil have been already done on some subspecies. Meanwhile till now there have not been carried out any researches on tocopherol isomers estimation in seabuckthorn seeds of $H$. rhamnoides subspecies mongolica, which widely grown in Siberia and considered as most promising subspecies within genus Hippophae L. This subspecies is represented by many so called ecotypes, which are grown in different regions, soil and climate conditions. The reason of current investigation was comparative estimation of tocopherol isomers composition in seed oil of different ecotypes of $H$. rhamnoides subspecies mongolica, growing in the same soil and climate conditions on experimental plots of Lisavenko Research Institute of Horticulture for Siberia.

\footnotetext{
* Corresponding author: anna-krysova@mail.ru
} 


\section{Materials and Methods}

Research has been carried out on facility of UBF GmbH laboratory (Germany) in 20142015. Samples have been collected on experimental plots of the Lisavenko Institute of Horticulture for Siberia in forest-steppe area of Altai Territory. All samples till evaluation kept for 6 months at temperature $-25^{\circ} \mathrm{C}$. As objects of investigation the following varieties have been taken: Dar Katuni, Novost Altaya - Katun ecotype; Chuyskaya - Chuya ecotype; Inja, Elizaveta - mutants (obtained by chemical mutagenesis); Velikan, Yantarnaya Sayan-Katun ecotype; Zhivko, 42-68-2 - Krasnoyarsk-Sayan ecotype; Lubimaya, Chulyshmanka - Sayan-Chulyshman ecotype; Zarja Dabat - Buryat ecotype.

Tocopherols estimation carried out by using Shimadzu Liquid Chromatograph LC-6 A, equipped by spectrophotometric detector Shimadzu SPD-6 AV. Tocopherols were identified by retention time and quantified using an external standard based on measurements of peak area values. As standards $\alpha-, \beta-, \gamma$ - and $\delta$-tocopherols have been used (Bestimmung der Tocopherole und Tocotrienole (Vitamin E) DGF-Einheitsmethoden F-II 4a, SOP 3.IV.02. ver. 1.).

\section{Results and discussion}

As a result of tocopherols estimation in lipids of seabuckthorn seeds it was established that $\alpha$-tocopherol is the major tocopherol isomer. Content of $\alpha$-tocopherol in Yantarnaya variety was higher $(4.8 \pm 1.9 \mathrm{mg} / 100 \mathrm{~g})$ compare to the rest of varieties. Lowest level of $\alpha$-isomer has been found in Dar Katuni variety $(2.1 \pm 1.6 \mathrm{mg} / 100 \mathrm{~g})$. Mean value of $\alpha$-tocopherol through all varieties is $3.5 \pm 0.3 \mathrm{mg} / 100 \mathrm{~g}$ (table 1 ).

Table 1. Tocopherol isomers content in lipids of seabuckthorn seeds, $\mathrm{mg} / 100 \mathrm{~g}$

\begin{tabular}{|c|c|c|c|c|c|}
\hline Ecotype & Variety & $\alpha$-toco & $\beta$-toco & $\gamma$-toco & $\delta$-toco \\
\hline Buryat & Zarja Dabat & $4.2 \pm 2.2$ & $0.4 \pm 0.3$ & $1.7 \pm 1.3$ & $0,3 \pm 0.2$ \\
\hline \multirow{2}{*}{ Katun } & Dar Katuni & $2.1 \pm 1.6$ & $0.3 \pm 0.2$ & $1.0 \pm 0.8$ & $0.2 \pm 0.1$ \\
\hline & Novost Altaya & $4.2 \pm 3.2$ & $0.8 \pm 0.2$ & $1.6 \pm 1.2$ & $0.8 \pm 0.6$ \\
\hline \multirow{2}{*}{$\begin{array}{l}\text { Krasnoyarsk- } \\
\text { Sayan }\end{array}$} & $42-68-2$ & $3.8 \pm 0.4$ & $0.3 \pm 0.0$ & $0.9 \pm 0.5$ & $0.3 \pm 0.2$ \\
\hline & Zhivko & $4.4 \pm 1.3$ & $0.4 \pm 0.2$ & $1.3 \pm 1.1$ & $0.2 \pm 0.0$ \\
\hline \multirow{2}{*}{ Mutants } & Elizaveta & $2.4 \pm 2.1$ & $0.5 \pm 0.0$ & $1.1 \pm 1.1$ & $1.5 \pm 1.2$ \\
\hline & Inja & $2.2 \pm 1.3$ & $0.3 \pm 0.1$ & $0.9 \pm 0.8$ & $3.5 \pm 3.3$ \\
\hline \multirow{2}{*}{ Sayan-Katun } & Velikan & $3.4 \pm 1.1$ & $0.5 \pm 0.2$ & $1.4 \pm 1.2$ & $0.2 \pm 0.0$ \\
\hline & Yantarnaya & $4.8 \pm 1.9$ & $0.7 \pm 0.4$ & $1.7 \pm 1.4$ & $0.1 \pm 0.1$ \\
\hline \multirow{2}{*}{$\begin{array}{c}\text { Sayan- } \\
\text { Chulyshman }\end{array}$} & Lubimaya & $2.6 \pm 0.7$ & $0.4 \pm 0.2$ & $0.9 \pm 0.7$ & $0.8 \pm 0.6$ \\
\hline & Chulyshmanka & $4.2 \pm 1.5$ & $0.6 \pm 0.2$ & $1.6 \pm 1.1$ & $0.3 \pm 0.1$ \\
\hline Chuya & Chuyskaya & $3.3 \pm 2.4$ & $0.9 \pm 0.5$ & $1.0 \pm 0.7$ & $0.6 \pm 0.5$ \\
\hline \multicolumn{2}{|c|}{$\overline{\mathrm{X}} \pm \mathrm{m}$} & $3.5 \pm 0.3$ & $0.5 \pm 0.1$ & $1.3 \pm 0.1$ & $0.7 \pm 0.3$ \\
\hline \multicolumn{2}{|c|}{$\min -\max$} & $2.1-4.8$ & $0.3-0.9$ & $0.9-1.7$ & $0.1-3.5$ \\
\hline \multicolumn{2}{|c|}{$\mathrm{V}, \%$} & 27.2 & 39.8 & 26.1 & 130.6 \\
\hline \multicolumn{2}{|c|}{$\mathrm{LSD}_{05}$} & $\mathrm{~F}_{\mathrm{f}}<\mathrm{F}_{05}$ & $\mathrm{~F}_{\mathrm{f}}<\mathrm{F}_{05}$ & $\mathrm{~F}_{\mathrm{f}}<\mathrm{F}_{05}$ & $\mathrm{~F}_{\mathrm{f}}<\mathrm{F}_{05}$ \\
\hline
\end{tabular}

Within years of investigation content of $\beta$-tocopherol in seabuckthorn seeds varied from $0.3 \pm 0.2$ (Dar Katuni) to $0.9 \pm 0.5 \mathrm{mg} / 100 \mathrm{~g}$ (Chuiskaya) with mean value at $0.5 \pm 0.1 \mathrm{mg} / 100$ $\mathrm{g}$ and variation of $39.8 \%$. Content of $\gamma$-tocopherol in lipids of seeds ranged from $0.9 \pm 0.5$ 
(42-68-2) to $1.7 \pm 1.3 \mathrm{mg} / 100 \mathrm{~g}$ (Zarja Dabat) and mean value $1.3 \pm 0.1 \mathrm{mg} / 100 \mathrm{~g}$. Elizaveta and Inja varieties accumulated highest volumes of $\delta$-tocopherol $-1.5 \pm 1.2$ and $3.5 \pm 3.3$ $\mathrm{mg} / 100 \mathrm{~g}$ respectively. Lowest level of $\delta$-tocopherol was noted in Yantarnaya variety $0.1 \pm 0.1 \mathrm{mg} / 100 \mathrm{~g}$. Mean amount of $\delta$-isomer is $0.7 \pm 0.3 \mathrm{mg} / 100 \mathrm{~g}$.

As regards comparative tocopherols content estimation between seabuckthorn ecotypes it has been noted that volumes of $\alpha$-tocopherol ranged from 2.3 \pm 1.7 (mutants) to $4.2 \pm 2.2$ $\mathrm{mg} / 100 \mathrm{~g}$ (Buryat ecotype). High level of this isomer has been found in seeds of SayanKatun and Krasnoyarsk-Sayan ecotypes. Content of $\beta$-tocopherol ranged from $0.3 \pm 0.1$ (Krasnoyarsk-Sayan ecotype) to $0.9 \pm 0.5 \mathrm{mg} / 100 \mathrm{~g}$ (Chuya ecotype). Highest level of $\gamma$ tocopherol in seeds has been accumulated by Buryat ecotype, while lowest level by Chuya ecotype $-1.7 \pm 1.3$ and $1.0 \pm 0.7 \mathrm{mg} / 100 \mathrm{~g}$ respectively. Mutants have been distinguished by highest volumes of $\delta$-tocopherol which accumulated up to $2.5 \pm 2.3 \mathrm{mg} / 100 \mathrm{~g}$. There have not been found any significant differences in tocopherol isomers content depending on year of investigation.

Most of results concerning tocopherol estimation that have been found in literature are about total content of tocopherols but not isomers one. That is why it is quite difficult to compare obtained results with represented in literature.

For instance according to [4] tocopherols content in seeds of Altai seabuckthorn is 14.3 $\mathrm{mg} / 100 \mathrm{~g}$. At the same time according to most recent investigations [5] tocopherols content in seeds of seabuckthorn is much higher and reported as about $62.15 \mathrm{mg} / 100 \mathrm{~g}$.

Some foreign researches like Beveridge et al. [6], Zhang et al. [7] reported about total content of tocopherols in seed oil from 61.0 to $113.0 \mathrm{mg} / 100 \mathrm{~g}$. According to Kallio et al. [8] tocopherols content is about $28.7 \mathrm{mg} / 100 \mathrm{~g}$, that much lower compare to previous authors. In 2017 group of researches from Slovakia carried out more comprehensive investigation of tocopherols content in seabuckthorn seeds. It has been reported that major tocopherol is $\alpha$-tocopherol, that in accordance with our results. The amount of $\alpha$-tocopherol in seabuckthorn seeds is about $70.0 \mathrm{mg} / 100 \mathrm{~g}$. $\beta$-, $\gamma$ - and $\delta$-isomers accumulated in lower amounts. For instance $\beta$-tocopherol content was $17.07 \mathrm{mg} / 100 \mathrm{~g}, \gamma$-tocopherol -45.85 $\mathrm{mg} / 100 \mathrm{~g}, \delta$-tocopherol $-9.47 \mathrm{mg} / 100 \mathrm{~g}$ [9]. These results are much higher compare to that obtained by our research. Because of lack of information on this topic, quite different results of them the further investigations and analyses are necessary.

\section{References}

1. N.M. Emmanuel, Y.N. Lyaskovskaya, Inhibition of lipid oxidation processes (Permagon Press, New York, 1961)

2. A.V. Trufanov, Biochemistry and physiology of vitamins and antivitamins (Moscow, 1959)

3. A. Abbasi, Functional analysis of tocopherol biosynthesis in plants (Aus Tehran: IRI, 2007)

4. D.A. Obodovskaya, A seabuckthorn as raw material for the vitamin industry (Moscow, 1957)

5. A.M. Zolotareva, M.G. Zayatueva, N. Bolorcecag, S.B. Rinchinov, J. Chemistry of plant raw materials 3, 177-183 (2015)

6. T. Beveridge, T.S.C. Li, B.D. Oomah, J. Agric. Food Chem. 47, 3480-3488 (1999)

7. W. Zhang, J. Yang, J. Duo, B. Ren, J. Guo, Proceedings of International Symposium on Sea Buckthorn (H. rhamnoides L.) 96-105 (Sian, 1989)

8. H. Kallio, B. Yang, P. Peippo, R. Tahvonen, R. Pan, J. Agric. Food Chem. 50, 30043009 (2002) 
9. Z. Burcovaa, F. Krepsa, S. Schmidta, M. Jablonsky, A. Haz, A. Sladkova, I. Surina, J. Acta Chimica Slovaca 10, 29-34 (2017) 